\title{
Age and Gender-Related Changes in Renal Haemodynamics of Albino Rats: The Possible Role of Cytokines and Prostaglandins
}

\author{
MOHAMED A. BENDARY, M.D.; SAFAA M. SALEH, M.D.; GHADA S. AMER, M.D. \\ ESSAM O. HENDIA, M.D. and RANA A. TAWFIK, M.Sc.
}

The Department of Medical Physiology, Faculty of Medicine, Menoufia University, Egypt

\begin{abstract}
Background: The normal aging process leads to changes in kidney morphology, hemodynamics and function, which are influenced by several factors, including gender. Females develop less age-dependent loss of renal function due to cardiorenal protective effects of estrogens.

Aim of Study: The aim of this study was to elucidate the age and gender-related changes in some renal haemodynamics in albino rats with special focusing on the role of cytokines and prostaglandins in establishment of such changes.

Material and Methods: Sixty albino rats (30 males \& 30 females) of local strain were divided into 2 major groups (Group I of male rats and Group II of female rats) was further subdivided into 3 subgroups: Young (4wk), young adult (3mo) and old (25mo). Body Weight (BW) and absolute Kidney Weight (KW) were measured. The Systolic Blood Pressure (SBP) of the rats was measured by the rat-tail plethysmography technique using a tail-cuff sphygmomanometer. The Renal Blood Flow Velocity (RBFV) and Renal Vascular Resistance (RVR) were measured using bi-directional blood flow meter with FFT-analysis. The blood samples were collected after a period of overnight fasting, left to be clotted, centrifuged and serum was separated for measurement of serum testosterone in male rats, serum estrogen in female rats, creatinine clearance, serum IL1beta, IL6 and serum PGE.
\end{abstract}

Results: The aging of male rat group is accompanied by change in the renal hemodynamic and some blood measurements. This is represented by significant increase in systolic blood pressure, renal vascular resistance, serum PGE, serum interleukin1-b \& 6, impaired renal function and significant decrease of renal blood flow. It was observed that the old female group had decreased in estrogen hormone level, which led to increase in systolic blood pressure, renal vascular resistance, serum PGE, serum interleukin1-b \& 6 and significant decrease renal blood flow.

Conclusion: Aging has a significant influence in renal hemodynamic (decrease of renal blood flow and increase of renal vascular resistance) and also, serum interleukin1-b \& 6 have a role in this change accompanied with pathophysiology of aging. Female is more protected from complications of the

Correspondence to: Dr. Mohamed A. Bendary, The Department of Medical Physiology, Faculty of Medicine, Menoufia University, Egypt kidney aging than male due to the previous effect of estrogen hormone.

Key Words: Aging - Renal Haemodynamics - Cytokines Prostaglandins - Rats.

\section{Introduction}

AGING in most species is associated with impaired adaptive and homeostatic mechanisms, leading to susceptibility to environmental or internal stresses with increasing rates of morbidity and mortality [1]. Age-related changes lead to a functional decline of several organs, including the kidney [2].

Aging is associated with progressive functional changes in the kidney. The Glomerular Filtration Rate (GFR) declines by $\sim 0.40$ to $1.02 \mathrm{~mL} / \mathrm{min}$ per year and mild changes in renal function with aging are often accompanied by tubular functional changes, which may not necessarily be recognized in humans unless they lead to disease or accentuation of a pathological condition. These changes include a reduction in sodium homeostasis associated with the loss of the ability to concentrate or dilute the urine to the degree seen in younger individuals [3]

Actually, there is also a sexual dimorphism in the aged kidney. Clinical studies showed that there is an age-related fall in GFR which is delayed in women and when they do occur, proceed relatively slowly [4]. In the rat, irrespective of strain, female gender confers marked protection from age-dependent declines in GFR, relative to males [5]

According to a number of reports in the literature, the causes of age-and sex related changes in renal haemodynamics are multifactorial and in that issue the role of cytokines and prostaglandins is not fully understood. Taking in account the implication of cytokines and prostaglandins in the pathophysiology of age and sex related changes in the 
kidney, we designed an experimental study to investigate the role of these substances on some renal haemodynamics in albino rats.

\section{Patients and Methods}

\section{Experimental animals:}

Sixty albino rats (30 males $\& 30$ females) of Sprague Dawley strain were used in this study. The rats were left to acclimatize without handling for one week prior to the start of the experiments. The rats were housed in well-ventilated cages at room temperature under the natural 12 hour day/ night cycle with free access to a standard commercial rodent chaw and water ad libitum throughout the whole study period. The experimental protocol of this study was revised and approved by the ethical guidelines established by the institutional review board committee of the Faculty of Medicine, Menoufia University from 2016-2018. The experimental procedures were performed in accordance with the international guiding principles for the care and use of research animals.

\section{Animal groups:}

The rats were randomly divided into 2 major groups (Group I of male rats and Group II of female rats). Each of these groups will be further subdivided into 3 subgroups of 10 rats each:

Group I (male rats):

- Subgroup IA (young males): 4 weeks old \& BW of 60-80gm.

- Subgroup IB (adult males): 3 months old \& BW of 180-200gm.

- Subgroup IC (old age males): 25 months old \& BW of 250-300gm.

Group II (female rats):

- Subgroup IIA (young females): 4 weeks old \& BW of 60-80gm.

- Subgroup IIB (adult females): 3 months old \& BW of 180-200gm.

- Subgroup IIC (Old age females): 25 months old $\&$ BW of 250-300gm.

\section{Experimental procedures:}

1-Anthropometric measures: BW and absolute $\mathrm{KW}$ by using a digital balance.

2- The rat-tail plethysmography technique: In this technique, conscious non-anesthetized rats were placed for 30 minutes before the actual measurements into a pre-heated plastic restrainer tube with the tail exposed to and this maneuver was repeated for 5 consecutive days for rats to be acclimatized to the rat tail cuff and the restrainer. Then, the pneumatic blood pressure cuff were put over the rat's tail then inflated over $200 \mathrm{mmHg}$ to occlude the pulse and was allowed to deflate slowly until the pulse pressure was observed. The pulse sign was monitored to see when the pulse signal began to be detected and reached the maximum pulse height. The start of pulsation was viewed on the tracing and was referenced to the pressure curve sign at that point; this point was analogous to SBP. Three traced record of both blood flow and cuff pressure plethysmogram for the same rat were recorded on 4-channel plethysmography (Harvard apparatus Ltd, Aden Berge, England) [6]

3- Bi-directional blood flow meter with FFTanalysis: Each rat was anesthetized with thiopental sodium in a dose of $50 \mathrm{mg} / \mathrm{kg}$ by intraperitoneal injection. Then, the rat was laid on its back and a midline laparotomy was made to expose the right renal artery. After setting the mode of pulsed blood flow meter (Doppler) we used ultrasonic probe pressed softly to the measured area at an angle of $40^{\circ}-50^{\circ}$. After hearing optimal sound, we wait for 5 seconds without moving the probe then press the freez key to freez the wave form, RBFV and RVR were mea-sured [7].

\section{4- Biochemical analysis:}

- Collection of 24hrs urine samples: Rats were placed in individual metabolic cages which placed over funnel, the top of funnel was coverd by wire mesh to avoid fecal contamination of urine. During urine collection the animal received free access to water but no food was given to avoid contamination [8]. The total voided urine volume $(\mathrm{ml} / \mathrm{min})$ during the next $24 \mathrm{hrs}$ and urinary creatinine concentration $(\mathrm{mg} / \mathrm{ml})$ were measured for calculation of creatinine clearance $(\mathrm{ml} / \mathrm{min})$ by using the formula: Creatinine clearance $=\mathrm{UXX}$ V/P [9]. U: Creatinine concentration in urine $(\mathrm{mg} / \mathrm{ml}), \mathrm{V}$ : Volume of urine per minute $(\mathrm{ml} / \mathrm{min})$. $\mathrm{P}$ : Creatinine concentration in plasma $(\mathrm{mg} / \mathrm{ml})$.

- At the end of the experiment, all rats were undergoing an overnight fasting, morning blood samples were withdrawn from all rats through the retro-orbital route using heparinized capillary tubes and the blood samples were allowed to clot for 30 minutes at room temperature. Then the blood samples were centrifuged at 10,000rpm for 20 minutes, the serum was separated and stored at $-20^{\circ} \mathrm{C}$ until used for estimation [10].

A- Kits for estimation of testosterone (enzyme immunoassay test kit, Catalog Number: 40101-325034, GenWay Biotech, Inc) [11]. 
B- Serum estrogen in female rats (enzyme immunoassay test kit, Catalog Number: BC- 1111, Bio Check, Inc, CA, USA) [11]

C- Serum IL1beta (ELISA Kit, Catalog Number: OKBB00177, Aviva Systems Biology) [12]

D- Serum IL6 (ELISA kits, Catalog Number: RAB0306 provided, Sigma-Aldrich Co.USA) [13].

E- Serum PGE level (Immunoassay, Catalog Number: KGE004, provided by R \& D Systems) [14].

\section{Statistical analysis:}

All results were presented as the mean \pm SD in each experimental group. The data were analyzed using statistical package the social sciences 19.0 for windows (SPSS; SPSS Inc., Chicago, Illinois, USA). In this study, the mean (X), (SD), $t$-test, one way analysis of variance (ANOVA), post hoc Least Significant Difference (LSD) were calculated. $p$-values $<0.05$ were considered statistically significant.

\section{Results}

The present study showed that, the adult male group showed significant increase in $\mathrm{BW}, \mathrm{KW}$, $\mathrm{SBP}, \mathrm{RBFV}$, testosterone and creatinine clearance (all $p<0.01$ ) significant reduction in $\mathrm{RVR}$, serum IL1beta, IL6 and serum PGE level (all $p<0.01$ ) when compared to the corresponding values in young male group. The old male group showed significant increase in BW, SBP, RVR, serum IL1beta, IL6 and serum PGE level (all $p<0.01$ ) significant reduction in RBFV, testosterone and creatinine clearance (all $p<0.01$ ) statistically insignificant in KW $(p>0.05)$ when compared to the corresponding values in adult male group (Tables $1,2)$.

The adult female group showed significant increase in $\mathrm{BW}, \mathrm{KW}, \mathrm{SBP}$, estrogen and creatinine clearance $(p<0.01, p<0.01, p<0.05, p<0.01, p<0.01$ respectively) significant reduction in serum IL1beta, IL6 and serum PGE (all $p<0.01$ ) level statistically insignificant in RBFV and RVR $(p>0.05)$ when compared to the corresponding values in young female group. The old female group showed significant increase in BW, SBP, RVR, serum IL1beta, IL6 and serum PGE level (all $p<0.01$ ) significant reduction in RBFV and estrogen (all $p<0.01$ ) statistically insignificant in KW and creatinine clearance $(p>0.05)$ when compared to the corresponding values in adult female group (Tables 3,4).
Table (1): Body Weight (BW), Kidney Weight (KW), Systolic Blood Pressure (SBP), Renal Blood Flow Velocity (RBFV) and Renal Vascular Resistance (RVR) in young, adult and old male groups.

\begin{tabular}{|c|c|c|c|}
\hline Parameter & Young male & Adult male & Old male \\
\hline BW (gm) & $61.87 \pm 8.37$ & $\begin{array}{l}231.45 \pm 10.43 \\
p_{1}<0.01\end{array}$ & $\begin{array}{l}274.65 \pm 28.25 \\
p_{1}<0.01 \\
p_{2}<0.01 \Pi\end{array}$ \\
\hline $\mathrm{KW}(\mathrm{gm})$ & $0.40 \pm 0.06$ & $\begin{array}{l}1.02 \pm 0.12 \\
p_{1}<0.01\end{array}$ & $\begin{array}{l}1.20 \pm 0.17 \\
p_{1}<0.01 \\
p_{2}<0.05\end{array}$ \\
\hline $\mathrm{SBP}(\mathrm{mmHg})$ & $89.2 \pm 2.9$ & $\begin{array}{l}103.3 \pm 4.5 \\
p_{1}<0.01\end{array}$ & $\begin{array}{l}127.5 \pm 4.8 \\
p_{1}<0.01 \\
p_{2}<0.01 \Pi\end{array}$ \\
\hline $\operatorname{RBFV}(\mathrm{cm} / \mathrm{sec})$ & $4.3 \pm 0.41$ & $\begin{array}{l}6.3 \pm 0.47 \\
p_{1}<0.01\end{array}$ & $\begin{array}{l}4.0 \pm 0.74 \\
p_{1}<0.05 \\
p_{2}<0.01 \Pi\end{array}$ \\
\hline RVR (RPU) & $0.93 \pm 0.04$ & $\begin{array}{l}0.81 \pm 0.04 \\
p_{1}<0.01\end{array}$ & $\begin{array}{l}1.23 \pm 0.08 \\
p_{1}<0.01 \\
p_{2}<0.01 \Pi\end{array}$ \\
\hline
\end{tabular}

Results are expressed as mean \pm SD $(n=6)$. Significance was considered when $p$-value was $<0.05$.

The mark $\propto$ and $\prod$ indicate the that value are significantly different, when comared withe corresponding values of young and adult male groups, respectively.

$p 1$ is set in comparison with the young group. $p 2$ is set in comparison with the adult group.

Table (2): Serum testosterrone creatinine clearance, serum Interleukin 1 beta (IL-1B) serum Interleukin 6 (IL6) and serum prostaglandin E2 (PGE2) in young, adult and old male groups.

\begin{tabular}{|c|c|c|c|}
\hline Parameter & Young male & Adult male & Old male \\
\hline $\begin{array}{l}\text { - Serum } \\
\text { testosterrone } \\
(\mathrm{ng} / \mathrm{ml})\end{array}$ & $0.11 \pm 0.05$ & $\begin{array}{l}3.91 \pm 0.56 \\
p_{1}<0.01\end{array}$ & $\begin{array}{l}1.04 \pm 0.34 \\
p_{1}<0.01 \\
p_{2}<0.01 \Pi\end{array}$ \\
\hline $\begin{array}{l}\text { - Creatinine } \\
\text { clearance } \\
(\mathrm{ml} / \mathrm{min})\end{array}$ & $0.35 \pm 0.04$ & $\begin{array}{l}1.31 \pm 0.23 \\
p_{1}<0.01\end{array}$ & $\begin{array}{l}0.75 \pm 0.1 \\
p_{1}<0.01 \\
p_{2}<0.01 \Pi\end{array}$ \\
\hline $\begin{array}{l}\text { - Serum IL-1B } \\
(\mathrm{pg} / \mathrm{ml})\end{array}$ & $114.5 \pm 7.89$ & $\begin{array}{l}37.3 \pm 10.14 \\
p_{1}<0.01\end{array}$ & $\begin{array}{l}72.6 \pm 5.31 \\
p_{1}<0.01 \\
p_{2}<0.01 \Pi\end{array}$ \\
\hline $\begin{array}{l}\text { - Serum IL-6 } \\
(\mathrm{pg} / \mathrm{ml})\end{array}$ & $100.2 \pm 5.8$ & $\begin{array}{l}18.4 \pm 2.87 \\
p_{1}<0.01\end{array}$ & $\begin{array}{l}55.7 \pm 5.5 \\
p_{1}<0.01 \\
p_{2}<0.01 \Pi\end{array}$ \\
\hline $\begin{array}{l}\text { - Serum PGE2 } \\
(\mathrm{pg} / \mathrm{ml})\end{array}$ & $0.61 \pm 0.11$ & $\begin{array}{l}0.13 \pm 0.01 \\
p_{1}<0.01\end{array}$ & $\begin{array}{l}0.43 \pm 0.08 \\
p_{1}<0.01 \\
p_{2}<0.01 \Pi\end{array}$ \\
\hline
\end{tabular}

Results are expressed as mean \pm SD (n=6). Significance was considered when $p$-value was $<0.05$.

The mark $\propto$ and $\prod$ indicate that the value are significantly different, when comared withe corresponding values of young and adult male groups, respectively.

$p 1$ is set in comparison with the young group $p 2$ is set in comparison with the adult group. 
Table (3): Body Weight (BW), Kidney Weight (KW), Systolic Blood Pressure (SBP), Renal Blood Flow Velocity (RBFV) and Renal Vascular Resistance (RVR) in young, adult and old female groups.

\begin{tabular}{|c|c|c|c|}
\hline Parameter & Young female & Adult female & Old female \\
\hline BW (gm) & $41.6 \pm 5.8$ & $\begin{array}{l}208.4 \pm 12.3 \\
p_{1}<0.01 *\end{array}$ & $\begin{array}{l}249.2 \pm 25.9 \\
p_{1}<0.01^{*} \\
p_{2}<0.01 \Omega\end{array}$ \\
\hline $\mathrm{KW}(\mathrm{gm})$ & $0.25 \pm 0.05$ & $\begin{array}{l}0.92 \pm 0.06 \\
p_{1}<0.01 *\end{array}$ & $\begin{array}{l}1.01 \pm 0.13 \\
p_{1}<0.01^{*} \\
p_{2}<0.05\end{array}$ \\
\hline $\mathrm{SBP}(\mathrm{mmHg})$ & $88.7 \pm 2.8$ & $\begin{array}{c}96.2 \pm 4.7 \\
p_{1}<0.01 *\end{array}$ & $\begin{array}{c}140.2 \pm 6.1 \\
p_{1}<0.01^{*} \\
p_{2}<0.01 \Omega\end{array}$ \\
\hline $\operatorname{RBFV}(\mathrm{cm} / \mathrm{sec})$ & $4.5 \pm 0.51$ & $\begin{array}{c}5.2 \pm 0.6 \\
p_{1}<0.05\end{array}$ & $\begin{array}{l}2.5 \pm 0.44 \\
p_{1}<0.01 * \\
p_{2}<0.01 \Omega\end{array}$ \\
\hline RVR (RPU) & $0.95 \pm 0.03$ & $\begin{array}{l}0.92 \pm 0.04 \\
p_{1}<0.05\end{array}$ & $\begin{array}{l}1.06 \pm 0.09 \\
p_{1}<0.05^{*} \\
p_{2}<0.01^{\Omega}\end{array}$ \\
\hline
\end{tabular}

Results are expressed as mean $\pm \mathrm{SD}(\mathrm{n}=6)$. Significance was considered when $p$-value was $<0.05$.

The mark * and $\Omega$ indicate that the value are significantly different, when comared withe corresponding values of young and adult female groups, respectively.

$p 1$ is set in comparison with the young group.

$p 2$ is set in comparison with the adult group.

Table (4): Serum estrogen, creatinine clearance, serum Interleukin 1 beta (IL-1B) serum Interleukin 6 (IL-6) and serum prostaglandin E2 (PGE2) in young, adult and old female groups.

\begin{tabular}{lccc}
\hline Parameter & Young female & Adult female & Old female \\
\hline - Serum & $6.5 \pm 0.9$ & $31.9 \pm 11.4$ & $14.7 \pm 1.0$ \\
$\begin{array}{l}\text { estrogen } \\
\text { (pg/ml) }\end{array}$ & & $p_{1}<0.01^{*}$ & $\begin{array}{l}p_{1}<0.05 \\
p_{2}<0.01^{\Omega} \Omega\end{array}$ \\
- Creatinine & $0.29 \pm 0.07$ & $0.66 \pm 0.11$ & $0.57 \pm 0.12$ \\
clearance & & $p_{1}<0.01^{*}$ & $p_{1}<0.01^{*}$ \\
(ml/min) & & & $p_{2}<0.05$ \\
- Serum IL-1B & $140.2 \pm 3.4$ & $30.9 \pm 3.3$ & $93.5 \pm 3.8$ \\
(pg/ml) & & $p_{1}<0.01^{*}$ & $p_{1}<0.01^{*}$ \\
& & & $p_{2}<0.01^{\Omega}$ \\
- Serum IL-6 & $120.6 \pm 1.5$ & $15.0 \pm 1.96$ & $68.7 \pm 1.1$ \\
(pg/ml) & & $p_{1}<0.01^{*}$ & $p_{1}<0.01^{*}$ \\
& & & $p_{2}<0.01^{\Omega}$ \\
- Serum PGE2 & $0.28 \pm 0.04$ & $0.12 \pm 0.01$ & $0.23 \pm 0.02$ \\
(pg/ml) & & $p_{1}<0.01^{*}$ & $p_{1}<0.01^{*}$ \\
& & & $p_{2}<0.01^{2} \Omega$
\end{tabular}

Results are expressed as mean \pm SD (n=6). Significance was considered when $p$-value was $<0.05$.

The mark * and $\Omega$ indicate that the value are significantly different, when comared withe corresponding values of young and adult female groups, respectively.

$p 1$ is set in comparison with the young group. $p 2$ is set in comparison with the adult group.

In the present investigation, the adult male showed significant increase in BW, SBP, RBFV, creatinine clearance and serum IL6 ( $p<0.01, p<0.05$, $p<0.01, p<0.01, p<0.05$ respectively) significant reduction in RVR $(p<0.01)$ statistically insignificant in $\mathrm{KW}$, serum IL1beta and serum PGE $(p>0.05)$ when compared to the corresponding values in adult female group. In the present investigation, the old male showed significant increase in RBFV, RVR, serum PGE and creatinine clearance $(p<0.01$, $p<0.01, p<0.01, p<0.05$ respectively) significant reduction in SBP, serum IL1beta and serum IL6 (all $p<0.01$ ) statistically insignificant in $\mathrm{BW}$ and $\mathrm{KW}(p>0.05)$ when compared to the corresponding values in old female group (Tables 5,6).

Table (5): Body Weight (BW), Kidney Weight (KW), Systolic Blood Pressure (SBP), Renal Blood Flow Velocity (RBFV), Renal Vascular Resistance (RVR), creatinine clearance, serum interleukin 1 beta (IL1B), serum interleukin 6 (IL-6) and serum prostaglandin E2 (PGE2) in adult male and adult female groups.

\begin{tabular}{|c|c|c|c|}
\hline Parameter & Adult male & Adult female & $p$-value \\
\hline - BW (gm) & $231.45 \pm 10.43$ & $208.4 \pm 12.3$ & $p<0.01$ \\
\hline • KW (gm) & $1.02 \pm 0.12$ & $0.92 \pm 0.06$ & \\
\hline - SBP (mmHg) & $103.3 \pm 4.5$ & $96.2 \pm 4.7$ & $p<0.05$ \\
\hline - $\operatorname{RBFV}(\mathrm{cm} / \mathrm{sec})$ & $6.3 \pm 0.47$ & $5.2 \pm 0.6$ & $p<0.01$ \\
\hline • RVR (RPU) & $0.81 \pm 0.04$ & $0.92 \pm 0.04$ & $p<0.01$ \\
\hline $\begin{array}{l}\text { - Creatinine } \\
\text { clearance } \\
(\mathrm{ml} / \mathrm{min})\end{array}$ & $1.31 \pm 0.23$ & $0.66 \pm 0.11$ & $p<0.01$ \\
\hline - $\underset{(\mathrm{pg} / \mathrm{ml})}{\text { Serum IL-1B }}$ & $37.3 \pm 10.14$ & $30.9 \pm 3.3$ & NS \\
\hline $\begin{array}{l}\text { - Serum IL-6 } \\
(\mathrm{pg} / \mathrm{ml})\end{array}$ & $18.4 \pm 2.87$ & $15.0 \pm 1.96$ & $p<0.05$ \\
\hline - Serum PGE2 & $0.13 \pm 0.01$ & $0.12 \pm 0.01$ & NS \\
\hline
\end{tabular}

Results are expressed as mean \pm SD $(n=6)$. Significance was considered when $p$-value was $<0.05$.

NS: Non Significant $(p>0.05)$.

Table (6): Body Weight (BW), Kidney Weight (KW), Systolic Blood Pressure (SBP), Renal Blood Flow Velocity (RBFV), Renal Vascular Resistance (RVR), creatinine clearance, serum Interleukin 1 beta (IL-1B), serum Interleukin 6 (IL-6) and serum prostaglandin E2 (PGE2) in old male and old female groups.

\begin{tabular}{|c|c|c|c|}
\hline Parameter & Old male & Old female & $p$-value \\
\hline • BW (gm) & $274.65 \pm 28.25$ & $249.2 \pm 25.9$ & NS \\
\hline - KW (gm) & $1.20 \pm 0.17$ & $1.01 \pm 0.13$ & \\
\hline - SBP (mmHg) & $127.5 \pm 4.8$ & $140.2 \pm 4.7$ & $p<0.01$ \\
\hline - $\mathrm{RBFV}(\mathrm{cm} / \mathrm{sec})$ & $4.0 \pm 0.74$ & $2.5 \pm 0.44$ & $p<0.01$ \\
\hline • RVR (RPU) & $1.23 \pm 0.08$ & $1.06 \pm 0.09$ & $p<0.01$ \\
\hline $\begin{array}{l}\text { - Creatinine } \\
\text { clearance } \\
(\mathrm{ml} / \mathrm{min})\end{array}$ & $0.75 \pm 0.1$ & $0.57 \pm 0.12$ & $p<0.05$ \\
\hline - $\underset{(\mathrm{pg} / \mathrm{ml})}{\text { Serum IL-1B }}$ & $72.6 \pm 5.31$ & $93.5 \pm 3.8$ & $p<0.01$ \\
\hline $\begin{array}{l}\text { - Serum IL-6 } \\
(\mathrm{pg} / \mathrm{ml})\end{array}$ & $55.7 \pm 5.5$ & $68.7 \pm 1.1$ & $p<0.01$ \\
\hline - $\begin{array}{l}\text { Serum PGE2 } \\
(\mathrm{pg} / \mathrm{ml})\end{array}$ & $0.43 \pm 0.08$ & $0.23 \pm 0.02$ & $p<0.01$ \\
\hline
\end{tabular}

Results are expressed as mean \pm SD $(n=6)$. Significance was considered when $p$-value was $<0.05$.

NS: Non Significant $(p>0.05)$. 


\section{Discussion}

The current study was designed to elaborate the age and gender changes of some renal hemodynamic in albino rats with special focusing on the role of cytokines and prostaglandins.

Aged group of both sex, in the present work it was noticed that Systolic Blood Pressure (SBP) aged rats was significantly higher than the corresponding value in adult rats.

Aging is a physiological process related to morphological and functional changes in both cardiovascular and autonomic nervous systems. The autonomic nervous system changes are in the form of increased sympathetic and decreased parasympathetic activity which is related to higher incidence of cardiovascular diseases and hypertension [15].

Age induced increase in resting sympathetic activity together with increased sensitivity of vascular wall to sympathomimitic vaso-active agent has been implicated in the development of systolic hypertension in elderly [16]

Also, with a decrease in arterial compliance Alberto et al., [17] reported that, there's increased responsiveness to sympathetic neuronal stimuli, as the aging process compromises sympathetic neural function, where $\beta$-receptors are down regulated, and reflexively, perhaps, higher levels of $\alpha$ mediated neural tone increase peripheral vascular resistance and raise blood pressure. Moreover, Lakatta and Levy, [18] stated that, the diminished $\beta$-adrenergic vasodilatation with age, coupled with unchanged $\alpha$-adrenergic vasoconstrictive state, coupled with a decreased connective tissue elasticity contributes to prevalence of increased BP with aging.

Nevertheless, the early manifestation of renal aging was reduced Renal Blood Flow (RBF) and increased renal vascular resistance as result of endothelial impairment that occur long before affection of kidney functions by aging process. Normal serum creatinine with reduced Glumerular Filteration Rat (GFR) represents an early, transient state in the progression of chronic renal disease (CKD) $[19,20]$.

In addition, Jan et al., [21] reported that, aging often affects renal function adversely and may lead to reductions in glomerular filtration rate, renal blood flow, and plasma rennin activity, and these combined with increased plasma volumes contribute to rise blood pressure with aging.
It was necessary then to assess the renal blood flow and renal artery resistance in the present study. It was noted that aging caused significant reduction in renal blood flow with increased renal vascular resistance when compared to corresponding values of adult rats.

Although not inevitable, the decrease in glomerular filtration rate with age is well documented [22]

Previous studies showed a differentiated role for no-dependent pathways in the kidneys of aged rats and suggested that the kidney is affected selectively by the age induced endothelium dysfunction, and that ageing is accompanied by significant differences in NO-related responses in the kidney which do not appear to affect blood flow to other organs. This age-dependent renal alterations occur mainly as a result of systemic NO-deficiency (not local intra-renal) $[23,24]$. Both in animals and in humans, increasing age reduces the ability of the endothelium to elicit endothelium $\AA$ ] dependent vasodilatations in vitro and in vivo ( $\mathrm{Ng}$ et al., 2015) [25] . Besides diminished EDHÅ] mediated relaxations (Kong et al., 2015) [26], reduced production of NO can contribute to the endothelial dysfunction associated with ageing.

There is substantial evidence that chronic NO deficiency occurs in various types of Chronic Renal Disease (CRD) and may contribute to progressive loss of function and evolving structural damage $[27,28]$. Further more elevated plasma ADMA levels (endogenous inhibitor of eNos) in healthy old age are correlated with declines in renal plasma flow [29]

It may be quite concieving that the correlation between the impairment of renal function and and vascular resistance is time dependent. In aged SHR decreased the Plasma creatinine (Pcr) level was accompanied by a decrease in renal blood flow and increased renal vascular resistance [30]

However, Delp et al., [31] reported that aged rats had lower blood flows to the white portion of rectus femoris muscle, spleen, thyroid and parathyroid glands, and prostate gland than adult rats.

In the present work it was noticed that serum interleukin 1 beta and serum interleukin 6 (IL-1 $\beta$ \& IL-6) aged rats was significantly higher than the corresponding value in adult rats.

Large studies have demonstrated that high plasma levels of IL-6 are correlated with greater disability, morbidity and mortality in the elderly [32] 
Moreover, high levels of IL-6, IL-1b and C reactive protein are significantly associated with poor physical performance and muscle strength in older people [33]; IL-1b levels are predictors of high diastolic pressure in the elderly [34].

Inflammation is increased within the aging kidney in humans, with pro inflammatory cytokines detectable in the serum correlating with age-related renal disease $[35,36]$. The increase of IL-6 may contribute, along with other proinflammatory factors, to the onset of many of the chronic age related diseases [37], and may also be associated with mortality [38] . Additionally, in elderly, a decrease in naive $\mathrm{T}$ cells may result in impaired acquired immune responses, whereas clonal expansion of CD25 null T cells may result in increased secretion of TNF-a and IL-6, resulting in an accelerated degree of inflammation.

In the present work it was noticed that serum interleukin 6 young rats was significantly higher than the corresponding value in adult rats.

Recently, pancreatic alpha cells have been identified as a primary target of IL- 6 actions, regulating alpha cell mass expansion and glucagon production and release.according to Fernández et al., alpha cell mass increased sharply shortly after birth but decreased significantly after weaning. Pancreatic alpha cell proliferation was as high as $2.5 \%$ at the beginning of suckling but diminished with time to $1.2 \%$ in adulthood. Similarly, alpha cell neoformation was remarkably high on postnatal day (PN) 4, whereas alpha cell apoptosis was low throughout the neonatal period. Moreover, Il6 mRNA exhibited developmental upregulation in the pancreas of suckling rats, with the highest expression on PN2 \& PN24 then progressively decreased until reaching undetectable values in adulthood [40].

In the present work it was noticed that serum prostaglandin E2 (PGE2) aged rats was significantly higher than the corresponding value in adult rats. Several reports have addressed PG production during aging. Most of the data seem to indicate that the production of inflammatory PGs such as PGE2, TXA2, PGH2, and PGG2 increase with advancing age, whereas cytoprotective PGs such as PGI2 decrease with age [41,42]. Macrophages from old mice are reported to produce more PGE2 than young mice, indicating the dysregulation of immune cells for proinflammatory conditions with age [43]. The old female (menopause) group showed significant decrease in estradiol hormone when compared to the corresponding values in adult female group. During menopause, serum estradiol concentrations fall to values similar to or lower than those in men of similar age [44]. The ovaries are the primary source of protective estrogen in women of reproductive age. During menopause, a changing hormone profile in the body causes important shifts in the levels of estrogen present in the female body. Overall, this change is primarily a large drop in the average amount of circulating estrogen. The falling level of estrogen is the primary cause of familiar menopause symptoms like hot flashes, mood swings, and appetite [45]. On the other hand, menopause induces deleterious effects on different organs and systems that have been shown to be counteracted by estrogens [46]. The SBP in the adult male group was significantly higher when compared with the corresponding value in the adult female group On the contrarily, the SBP in the old male group significantly lower when compared with the corresponding value in the old female group because the endothelial effects of oestrogen involves mainly activation of eNOS and a greater production of NO, ER a stimulation also can augment the production of prostacyclin [47] and EDH-mediated responses [48]. The acute and chronic potentiating effect of oestrogens on endothelium-dependent relaxations involve both genomic and non-genomic effects [49]. It depends presumably on both a reduction in oxidative stress leading to an increased bioavailability of endothelium-derived $\mathrm{NO}$ and an increased responsiveness of the vascular smooth muscle cells to vasodilator stimuli [50].

Thus, endothelium dependent relaxations are more pronounced in arteries from premenopausal female than male animals [51]. Likewise, to judge from the reduced flow-mediated vasodilatation, endothelial responsiveness is blunted in post menopausal women, a condition which is due in part to BH4 deficiency [52], and the development of endothelial dysfunction is less prominent in premenopausal women than in age matched men and postmenopausal women, highlighting the protective effect of oestrogens [52]. According to Poehlman et al., (1997) [53] who concluded that blood pressure generally increases after menopause. Likewise, postmenopausal women have a higher risk of high blood pressure than do premenopausal women which, suggests that the hormonal and biochemical changes of menopause may play a role in high blood pressure. Menopause-related hormonal changes can lead to increased salt sensitivity and weight gain which, in turn, can lead to higher blood pressure. As levels of estrogen decrease, a woman's risk of developing high blood pressure increases dramatically. Because of the interplay of other 
hormones, such as progestin, and the effect that estrogen has on other important risk factors, postmenopausal women are actually at higher risk for developing high blood pressure than are men [54]

The mean RBFV in the adult male group was significantly higher when compared with the corresponding value in the adult female group due to in adult female higher renal vascular resistance than male that might protect female from increased PGC thus accounting for the sex dependent protection exhibited by females in aging, ablation, etc. induced glomerular injury $[\mathbf{5 5 , 5 6 ]}$. In rats, however, there is a clear sex difference with females of most strains exhibiting substantial protection [57]. Also, the mean RBFV in the old male group was significantly higher when compared with the corresponding value in the old female group due to decrease estradiol hormone produced by the ovaries estrogen act as vasodilator agent [58].

Estrogen directly regulates vasomotor tone through both short-term and long-term effects on the vasculature. Long-term effect of estrogen is associated with decreased plasma concentrations of renin [59] angiotensin-converting enzyme [60] and endothelin-1 [61] and decreased vascular expression of the gene for angiotensin II receptor type 1 [62] as well as an increased ratio of nitric oxide to endothelin-1 in plasma [63]. The net effect of these changes is to promote vasodilatation. Estrogen has been associated with increased resistance to hypertension and slower kidney aging in female subjects [64].

The glomular filteration rate in the male group significantly higher when compared with the corresponding value in the female group as indicated by the creatinine clearance. It has been demonstrated that GFR is lower in young adult females compared to aged-matched males, who present a higher RVR. Because women start with a somewhat lower GFR, the final value of GFR in advanced age is usually lower in women than in men. In experimental studies on rats, females were found to be protected from age-dependent declines in GFR compared to males [65]. The rate of progression of chronic renal disease is also faster in men than in premenopausal women [66], and this protection disappears after menopause but can be restored with estradiol replacement [67].

IL-6 in the adult male group was significantly higher when compared with the corresponding value in the adult female group due to estrogen has been reported to exert anti-inflammatory effects [68,69]. Numerous studies over the last decade have shown that G-Protein-coupled Estrogen Receptor (GPER) mediates rapid non-genomic signals of estrogens) [70,71]. GPER inhibits Tumor Necrosis Factor Alpha $(\mathrm{TNF}(\mathrm{x})$-induced expression of Interleukin 6 (IL-6), one of the representative inflammatory cytokines. Furthermore, this inhibition was mediated via down-regulation of the nuclear factorkappa B (NF jB) promoter activity by GPER [72]

Il $1 \mathrm{~b}$ and IL-6 in the old female group was significantly higher when compared with the corresponding value in the old male group. Transcriptomic analysis of peripheral mononuclear blood cells of young and elderly individuals revealed that significantly more pathways were altered in women than men in particular highlighting lower $\mathrm{T}$-cell defense and more inflammation in female seniors [73]. Pronounced endocrine changes alter the expression of inflammatory mediators thereby elevating plasma IL-1 0 , IL-6, IL-10, and TNF-a with menopause [74]

In the present work relation between sex hormone level and significant impairment of renal functions as assessed by creatinine clearance in aged rats when compared to corresponding values in adult rats.

According to Baylis, [75] reported that aging affects normal gonadal function. The most important changes include decreases in E2 and testosterone levels in females and males, respectively, and this decline in sex hormone production is also associated with a deterioration of renal function.

Testosterone levels decrease with normal aging as kidney function declines and decrease further in men with renal disease. If testosterone had renal protective actions, the gradual decline in testosterone levels that occurs in the elderly could contribute to the age-dependent renal dysfunction. However, testosterone levels are increased in most postmenopausal women as renal dysfunction develops and cardiovascular risk increases [76], suggesting that augmented testosterone levels might be damaging. Age-related changes in renal structure and function have been extensively studied in different species [77].

Studies suggest that E2 is responsible for the resistance of kidneys to the progression of renal disease in women [78,79]. In contrast, in men, the progression of chronic renal failure occurs at a faster rate than it does in women [80], indicating that gender can be considered one of the determinants of the progression of the age-related decline in renal function [81]. 
Renal damage progresses more slowly in females compared to males or ovariectomized females [82].

\section{Conclusion:}

Aging has a significant influence in renal hemodynamic (decrease of renal blood flow and increase of renal vascular resistance) and also, serum interleukin $1-b \& 6$ have a role in this change accompanied with pathophysiology of aging. Female is more protected from complications of the kidney aging than male due to the previous effect of estrogen hormone.

\section{References}

1- CAMPBELL K.H. and O'HARE A.M.: "Kidney disease in the elderly: Update on recent literature," Current Opinion in Nephrology and Hypertension Vol. 17, No. 3, pp. 298-303, 2008.

2- DAVIES I., FOTHERINGHAM A.P. and FARAGHER B.E.: "Age associated changes in the kidney of the laboratory mouse," Age and Ageing, Vol. 18, No. 2, pp. 12733, 1989.

3- WETZELS J.F., KIEMENEY L.A., SWINKELS D.W., WILLEMS H.L. and DEN HEIJER M.: Age-and genderspecific reference values of estimated GFR in Caucasians: The Nijmegen Biomedical Study. Kidney Int., 72: 6327, 2007.

4- WESSON L.G.: Physiology of the Human Kidney. Grune and Stratton; New York. Renal hemodynamics in physiological states p. 96-108, 1969.

5- BAYLIS C. and CORMAN B.: "The aging kidney: Insights from experimental studies," Journal of the American Society of Nephrology Vol. 9, No. 4, pp. 699-709, 1998.

6- ULLIAN M., ISLAM M., ROBINSON C., FITZGIBBON W., TOBIN E. and PAUL R.: Resistance to mineralocorticoids in Wistar-Furth rats. Am. J. Physiol., 272: 145461, 1997.

7- HAYWOOD J.R., SHAFFER R.A. and FASTENOW C., FINK G.D. and BRODY M.J.: Regional blood flow measurement with pulsed Doppler flowmeter in conscious rat. Am. J. Physiol., 241: H273-h8, 1981.

8- DANESHGARI F., HUANG X., LIU G., et al.: Temporal differences in bladder dysfunction caused by diabetes, diuresis, and treated diabetes in mice. Am. J. Physiol. Regul. Integr. Comp. Physiol., 290: R1728-R35, 2006 b.

9- SCHLATZER D., MAAHS D.M., CHANCE M.R., et al.: Novel urinary protein biomarkers predicting the development of microalbuminuria and renal function decline in type 1 diabetes. Diabetes Care, 35 (3): 549-55, 2012.

10- NISHIZAWA H., SHIMOMURA I., KISHIDA K., MAEDA N. and KURIYAMA H.: Androgens decrease plasma adiponectin, an insulin-sensitizing adipocyte-derived protein, 51: 2734-41, 2002.

11- TIETZ N.W: Clinical Guide to Laboratory Tests, 3 rd Ed., W.B. Saunders Company; Philadelphia, PA 19106, 1995.

12-LANGDAHL B.L., LOKKE E., CARSTENS M., STENKJAER L.L. and ERIKSEN E.F.: Osteoporotic fractures are associated with an 86-base pair repeat polymorphism in the interleukin-1-receptor antagonist gene but not with polymorphisms in the interleukin-1 beta gene. J. Bone Miner. Res., 15: 402-14, 2000.

13- ENGVALL E. and PERLMANN P.: Enzyme linked immunosorbent assay (ELISA): Quantitative assay of immunoglobulin G. Immunochemistry, 8: 871-4, 1971.

14- IVANOV A.I. and ROMANOVSKY A.A.: Front. Biosci., 9: 19-77, 2004.

15- BACKER G., AMBROSIONI E. and BORCH-JONHSEN K.: European guidelines on cardiovascular disease prevention in clinical practise. Third Joint Task Force of European and other Societies on Cardiovascular Disease Prevention in Clinical Practise. Eur. J. Cardiovascular. Prev. Rehab., 10 (Suppl 1): S1-S78, 2003.

16- KRUM H., SCHLAICH M., WHITBOURN R., SOBOTKA P.A., SADOWSKI J., BARTUS K., KAPELAK B., WALTON A., SIEVERT H., THAMBAR S., ABRAHAM W.T. and ESLER M.: Catheter-based renal sympathetic denervation for resistant hypertension: A multi centre safety and proof-of-principle cohort study. Lancet, 373 (9671): 1275-81, 2009.

17- ALBERTO U., FERRARI, ALBERTO R. and MARCO C.: Aging and the cardiovascular system. J. Appl. Physiol., 95: 2591-7, doi: 10. 1152, 2003.

18-LAKATTA E.G. and LEVY D.: Arterial and cardiac aging: Major shareholders in cardiovascular disease enterprises: Part I: Aging arteries: A "set up" for vascular disease. Circulation, 107: 139-46, 2003.

19- XIONG Y., YUAN L.W., DENG H.W., LI Y.J. and CHEN M.B.: Elevated Serum Endogenous Inhibitor of Nitric Oxide Synthase and Endothelial Dysfunction in Aged Rats. Clinical and Experimental Pharmacology and Physiology, 28 (10): 842-7, 2002.

20- GIANNELLI S.V., PATEL K.V., WINDHAM B.G., PIZZARELLI F., FERRUCCI L. and GURALNIK J.M.: Magnitude of Underascertainment of Impaired Kidney Function in Older Adults with Normal Serum Creatinine. J. Am. Geriatr. Soc., 55 (6): 816-23, 2007.

21- JAN T.K., STEFANIE M.B., BOGER, HERMAN H. and DANILO FLISER: Functional changes in the aging kidney: Is there a role for asymmetric dimethyl arginine? Nephrol. Dial. Transplant., 18: 1245-8, 2003.

22- JOLES J.A. and POSTON L.: Can exercise prevent preeclampsia? J. Hypertension, 28: 2384-5, 2010.

23- HILL C., LATEEF A.M., ENGELS K., SAMSELL L. and BAYLIS C.: Basal and stimulated nitric oxide in control of kidney function in the aging. Am. J. Physiol., 272 (6 Pt 2): R1747-53, 1997.

24- TAN D., CERNADAS M.R., ARAGONCILLO P., CASTILLA M.A., ARROYO M.A., FARRÉ A.J., CASADO S. and CARAMELO C: Role of nitric oxide-related mechanisms in renal function in ageing rats. Nephrol. Dial. Transplant, 13: 594-601, 1998.

25- NG H.H., JELINIC M., PARRY L.J. and LEO C.H.: Increased superoxide production and altered nitric oxidemediated relaxation in the aorta of young but not old male relaxin-deficient mice. Am. J. Physiol. Heart Circ. Physiol., 309, H285-H296, 2015. 
26- KONG B., MAN R., GAO Y., VANHOUTTE P. and LEUNG S.W.: Reduced activity of SKCa and Na-K ATPase underlies the accelerated impairment of EDHÅ] type relaxations in mesenteric arteries of aging spontaneously hypertensive rats. Pharmacol. Res. Perspect., 3, e00150, 2015.

27- BAYLIS C.: Nitric oxide deficiency; both consequence and cause of Chronic Renal Disease (CRD) Hypertens Nephrol., 5: 193-201, 2001.

28- BAYLIS C.: Changes in renal hemodynamics and structure in the aging kidney; sexual dimorphism and the nitric oxide system. Exp. Gerontol., 40 (4): 271-8, 2005.

29- KIELSTEIN J.T., BODE-BOGER S.M., FROLICH JC, RITZ E., HALLER H. and FLISER D.: Asymmetric dimethylarginine, blood pressure, and renal perfusion in elderly subjects. Circulation, 107: 1891-5, 2003.

30- STANOJEVIC' M.N., VARAGIC' J., JOVOVICC' D., MILORADOVIC' Z., LIPKOVSKI M.J. and JERKIC' M.: Aging and hypertension as factors of progressive renal failure. Med. Pregl., 56 (1): 59-64, 2003.

31- DELP M.D., EVANS M.V. and DUAN C.: Effects of aging on cardiac output, regional blood flow, and body composition in Fischer-344 rats. J. Appl. Physiol., 85 (5): 1813-22, 1998.

32- FERRUCCI L., HARRIS T.B., GURALNIK J.M., TRACY R.P., CORTI M.C., COHEN H.J., PENNINX B., PAHOR M., WALLACE R. and HAVLIK R.J.: Serum IL-6 level and the development of disability in older persons. J. Am. Geriatr. Soc., 47: 639-46, 1999.

33- CESARI M., PENNINX B.W., PAHOR M., LAURETANI F., CORSI A.M., RHYS WILLIAMS G., GURALNIK J.M. and FERRUCCI L.: Inflammatory markers and physical performance in older persons: The InCHIANTI study. J. Gerontol. A Biol. Sci. Med Sci., 59: 242-8, 2004.

34- BARBIERI M., FERRUCCI L., CORSI A.M., MACCHI C., LAURETANI F., BONAFÈ M., OLIVIERI F., GIOVAGNETTI S., FRANCESCHI C. and PAOLISSO G.: Is chronic inflammation a determinant of blood pressure in the elderly? Am. J. Hypertens., 16: 537-43, 2003.

35- SARKAR D. and FISHER P.B.: Molecular mechanisms of aging-associated inflammation. Cancer. Lett., 236: 1323, 2006.

36- COSTELLO W.R., RYFF C.D. and COE C.L.: Aging and low-grade inflammation reduce renal function in middleaged and older adults in Japan and the USA. Age (Dordr), 37: 9808,2015

37- WILLIAMS K., THOMSON D., SETO I., et al.: Age groups for pediatric trials. Pediatrics 129 (Suppl 3): S 15360, 2012.

38- SACKS D., FINDLEY S., FRAPPIER J.Y., et al.: Age limits and adolescents. Paediatr Child Health, 8: 577-8, 2003.

39- KIM H.O., KIM H.S., YOUN J.C., SHIN EC and PARK S.: Serum cytokine profiles in healthy young and elderly population assessed using multiplexed bead-based immunoassays. J. Transl. Med., 9: 113, 2011.

40- FERNÁNDEZ E., DE TORO J., LIZÁRRAGA M., ESCRIVÁ F. and ÁLVAREZC: Role of endogenous IL-6 in the neonatal expansion and functionality of Wistar rat pancreatic alpha cells. Diabetologia, Volume, 56, Issue 5, pp. 1098-107, 2013.

41- BEHARKA A.A., WU D., HAN S.N. and MEYDANI S.N.: Macrophage prostaglandin production contributes to the age-associated decrease in T-cell function which is reversed by the dietary antioxidant vitamin E. Mech. Ageing Dev., 93: 59-77, 1997.

42- NAKAJIMA M., HASHIMOTO M., WANG F., YAMANAGA K., NAKAMURA N., UCHIDA T. and AMANOUCHI K.: Aging decreases the production of PGI2 in rat aortic endo-thelial cells. Exp. Gerontol., 32: 685-693, 1997.

43- HAYEK M.G., MURA C., WU D., BEHARKA A.A., HAN S.N., PAULSON K.E., HWANG D. and MEYDANI S.N.: Enhanced expression of inducible cyclooxygenase with age in murine macrophages. J. Immunol., 159: 2445$51,1997$.

44- YEN S.S. and JAFFE R.B.: Reproductive endocrinology: Physiology, pathophysiology and clinical management. $3^{\text {rd }}$ ed. Philadelphia: W.B. Saunders, 1991. MISHELL DR: Menopause. In MA Stenchever et al., eds., Comprehensive Gynecology, 4th ed., pp. 1217-58, 2001.

45- MISHELL D.R.: Menopause. In MA Stenchever et al., eds., Comprehensive Gynecology 4 th ed., pp. 1217-58. St. Louis: Mosby, 2001.

46- CASTILLO C., CEBALlOS G., RODRIGUEZ D., VILLANUEVA C., MEDINA R., LOPEZ J., MENDEZ E. and CASTILLO E.F.: Effect of estradiol on phenylephrine contractility associated with intracellular calcium release in rat aorta. Am. J. Physiol. Cell. Physiol., 291 (6): C 138894, 2006.

47- JOBE S.O., RAMADOSS J., WARGIN A.J. and MAGNESS R.: Estradiol-17beta and its cytochrome P450-and catechol-O-methyltransferase-derived metabolites selectively stimulate production of prostacyclin in uterine artery endothelial cells: Role of estrogen receptor-alpha versus estrogen receptor-beta. Hypertension, 61: 509-18, 2013.

48- KONG B., MAN R., GAO Y., VANHOUTTE P. and LEUNG S.W.: Reduced activity of SKCa and Na-K ATPase underlies the accelerated impairment of EDH-type relaxations in mesenteric arteries of aging spontaneously hypertensive rats. Pharmacol. Res. Perspect., 3: e00150, 2015.

49- MILLER V.M. and DUCKLES S.P.: Vascular actions of estrogens: Functional implications. Pharmacol. Rev., 60: 210-41, 2008

50- MAZZUCA M.Q., MATA K.M., LI W., RANGAN S.S. and KHALIL R.A.: Estrogen receptor subtypes mediate distinct microvascular dilation and reduction in $\left[\mathrm{Ca}^{2+}\right.$ $\mathrm{I}$ in mesenteric microvessels of female rat. J. Pharmacol. Exp. Ther., 352: 291-304, 2015.

51- ZULOAGA K.L., DAVIS C.M., ZHANG W. and ALKAYED N.J.: Role of aromatase in sex-specific cerebrovascular endothelial function in mice. Am. J. Physiol. Heart Circ. Physiol., 306, H929-H37, 2014.

52- MOREAU K.L., MEDITZ A., DEANE K.D. and KOHRT W.M.: Tetrahydrobiopterin improves endothelial function and decreases arterial stiffness in estrogen $\AA$ ] deficient postmenopausal women. Am. J. Physiol. Heart Circ. Physiol., 302, H1211-H8, 2012. 
53- POEHLMAN E.T., TOTH M.J. and ADES P.A.: Menopause-associated changes in plasma lipids, insulin-like growth factor I and blood pressure; European Journal of Clinical Investigation, 27 (4): 322-6, 1997.

54- BELLIPANNI G.D., MARZO F., BLASI F. and MARZO A.: Effects of melatonin in perimenopausal and menopausal women: Our personal experience. Ann. N.Y. Acad. Sci., 1057: 393-402, 2005.

55- MUNGER K. and BAYLIS C.: Sex differences in renal hemodynamics in rats. Am. J. Physiol., 254: F223-F231, 1988.

56- BAYLIS C.: Age-dependent glomerular damage in the rat: Dissociation between glomerular injury and both glomerular hypertension and hypertrophy. Male gender as a primary risk factor. J. Clin. Invest., 94: 1823-9, 1994.

57- ERDELY A., GREENFELD Z., WAGNER L. and BAYLIS C.: Sexual dimorphism in the aging kidney; inverse relationship between injury and nitric oxide system. Kidney Int., 63: 1021-6, 2003.

58- MENDELSOHN M.E. and KARAS R.H.: The Protective Effects of Estrogen on the Cardiovascular System Volume, 340: 1801-11, 1999.

59- SCHUNKERT H., DANSER A.H.J., HENSE H.W., DERKX F.H.M., KURZINGER S. and RIEGGER G.A.J.: Effects of estrogen replacement therapy on the reninangiotensin system in postmenopausal women. Circulation, 95: 39-45, 1997.

60- PROUDLER A.J., AHMED A.I., CROOK D., FOGELMAN I., RYMER J.M. and STEVENSON J.C.: Hormone replacement therapy and serum angiotensin-convertingenzyme activity in postmenopausal women. Lancet, 346 : 89-90, 1995.

61- YLIKORKALA O., ORPANA A., PUOLAKKA J., PYORALA T. and VIINIKKA L.: Postmenopausal hormonal replacement decreases plasma levels of endothelin-1. J. Clin. Endocrinol. Metab., 80: 3384-7, 1995.

62- NICKENIG G., BAUMER A.T., GROHE C., KAHLERT S., STREHLOW K., ROSENKRANZ S. and STÄBLEIN A.: Estrogen modulates AT 1 receptor gene expression in vitro and in vivo. Circulation, 97: 2197-201, 1998.

63- BEST P.J.M., BERGER P.B., MILLER V.M. and LERMAN A.: The effect of estrogen replacement therapy on plasma nitric oxide and endothelin-1 levels in postmenopausal women. Ann. Intern. Med., 128: 285-8, 1998.

64- BONGARTZ L.G., BRAAM B., VERHAAR M.C., CRAMER M.J., GOLDSCHMEDING R., GAILLARD C.A., STEENDIJK P., DOEVENDANS P.A. and JOLES J.A.: Transient nitric oxide reduction induces permanent cardiac systolic dysfunction and worsens kidney damage in rats with chronic kidney disease. Am. J. Physiol. Regul. Integr. Comp. Physiol., 298: R815-R23, 2010.

65- BAYLIS C. and CORMAN B.: The aging kidney: Insights from experimental studies. J. Am. Soc. Nephrol., 9: 699709,1998

66- NEUGARTEN J., ACHARYA A. and SILBIGER S.R.: Effect of gender on the progression of nondiabetic renal disease: A meta-analysis. J. Am. Soc. Nephrol., 11: 31929, 2000.

67- DUBEY R.K. and JACKSON E.K.: Estrogen-induced cardiorenalnprotection: Potential cellular, biochemical, and molecular mechanisms. Am. J. Physiol. Renal. Physiol., 280: F365-F88, 2001.

68- CHAKRABARTI S., LEKONTSEVA O. and DAVIDGE S.T.: Estrogen is a modulator of vascular inflammation. IUBMB Life, 60: 376-82, 2008.

69- GOLD S.M. and VOSKUHL R.R.: Estrogen and testosterone therapies in multiple sclerosis. Progress in Brain Research, 175: 239-51, 2009.

70- MIZUKAMI Y.: In vivo functions of GPR30/GPER-1, a membrane receptor for estrogen: From discovery to functions in vivo. Endocrine Journal, 57: 101-7, 2010.

71- FILARDO E.J., THOMAS P. and MINIREVIEW: G protein-coupled estrogen receptor-1, GPER-1: Its mechanism of action and role in female reproductive cancer, renal and vascular physiology. Endocrinology, 153: 2953$62,2012$.

72- OKAMOTO M. and MIZUKAMI Y.: GPER negatively regulates TNFalpha-induced IL-6 production in human breast cancer cells via NF-kappaB pathway. Endocrine Journal, 63: 485-93, 2016.

73- MARTTILA S., JYLHÄVÄ J., NEVALAINEN T., NYKTER M., JYLHÄ M., HERVONEN A., TSEREL L., PETERSON P. and HURME M.: Transcriptional analysis reveals gender-specific changes in the aging of the human immune system. PLoS ONE, 8: e66229, 2013.

74- YASUI T., MAEGAWA M., TOMITA J., MIYATANI Y., YAMADA M., UEMURA H., MATSUZAKI T., KUWAHARA A., KAMADA M., TSUCHIYA N., YUZURIHARA M., TAKEDA S. and IRAHARA M.: Changes in serum cytokine concentrations during the menopausal transition. Maturitas, 56: 396-403, 2007.

75- BAYLIS C.: Sexual dimorphism in the aging kidney: Differences in the nitric oxide system. Nat. Rev. Nephrol., 5: 384-96, 2009.

76- RECKELHOFF J.F. and BAYLIS C.: Glomerular metalloprotease activity in the aging rat kidney: Inverse correlation with injury. J. Am. Soc. Nephrol., 3: 1835-8, 1993.

77- BAYLIS C. and CORMAN B.: The aging kidney: Insights from experimental studies. J. Am. Soc. Nephrol., 9: 699709, 1998

78- BAYLIS C.: Sexual dimorphism in the aging kidney: Differences in the nitric oxide system. Nat. Rev. Nephrol., 5: 384-96, 2009.

79- DUBEY R.K. and JACKSON E.K.: Estrogen-induced cardiorenal protection: Potential cellular, biochemical, and molecular mechanisms. Am. J. Physiol. Renal. Physiol., 280: F365- F88, 2001.

80- NEUGARTEN J., ACHARYA A. and SILBIGER S.R.: Effect of gender on the progression of nondiabetic renal disease: A meta-analysis. J. Am. Soc. Nephrol., 11: 31929, 2000.

81- ERDELY A., GREENFELD Z., WAGNER L. and BAYLIS C.: Sexual dimorphism in the aging kidney: Effects on injury and nitric oxide system. Kidney Int., 63: 1021-6, 2003.

82- SASSER J.M., AKINSIKU O., MONINGKA N.C., JERZEWSKI K., BAYLIS C., LEBLANC A.J., KANG L.S., SINDLER A.L. and MULLER-DELP J.M.: Sexual dimorphism in development of kidney damage in aging Fischer344 rats. Gend. Med., 9: 219-31, 2012. 


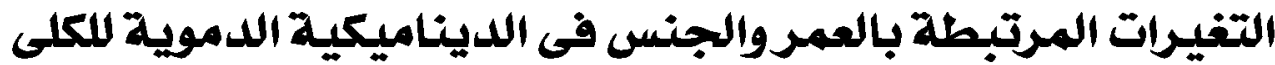

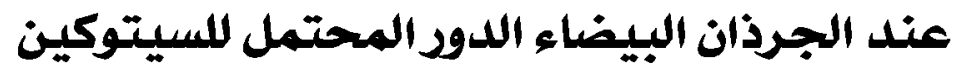 والبروستاجلاندين}

المقدمة: تعرف الشيخوخة على أنها الهبوط التدريجى اللوظانف والخصوية مع زيادة معدل الإصابة بالأمراض والموفاة. يعد من أهم التغيرات

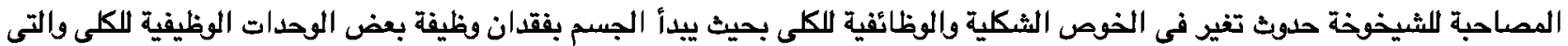
تسمى النفرونات.

مواد وطرق البحث: لقد أجريت هذه الدراسة على ستون جرذ أبيض من السلالة المحلية تم تقسيمهم إلى ب مجموعات (المجموعة الناشئة

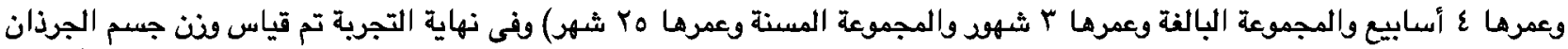

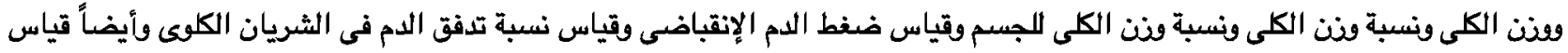

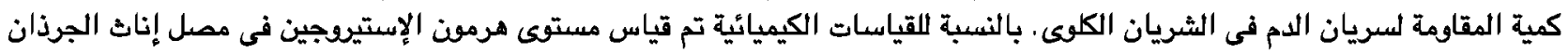

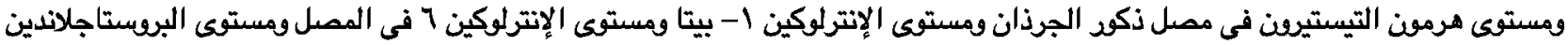
E2 Eي Eم مصل وظائف الكلى.

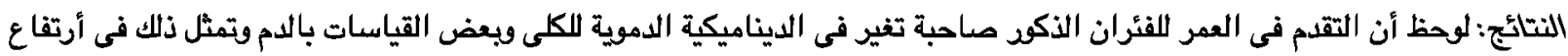

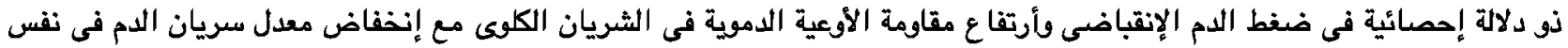

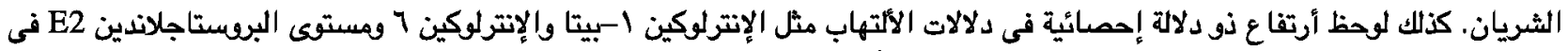

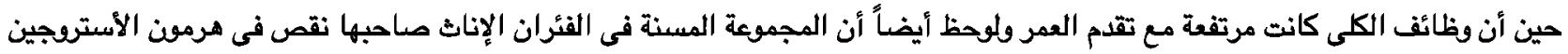

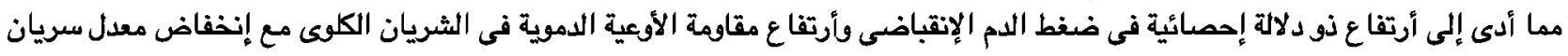

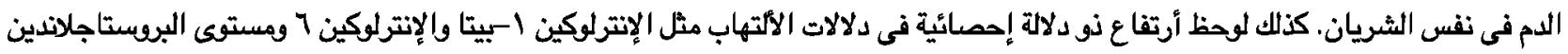

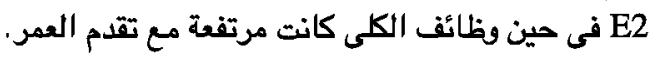

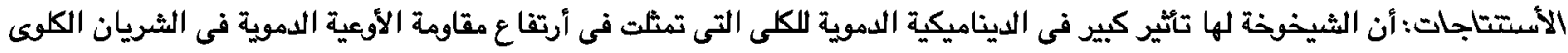

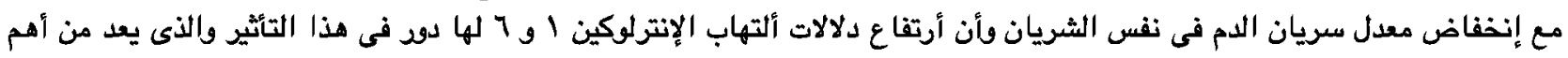

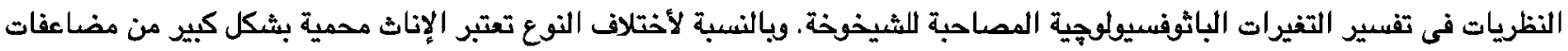

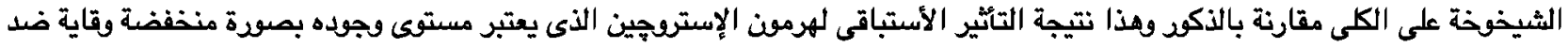
إنففاض وظائف الكلى عند الإناث. 